\title{
Seasonal Fluctuations in the Occurrence of Abnormal Enlargement of the Ovary of Pacific Oyster Crassostrea gigas at Gokasho Bay, Mie, Japan
}

\author{
Sonomi Imanaka ${ }^{1}$, Naoki Itoh ${ }^{2}$, Kazuo Ogawa $^{2 *}$ and Hisatsugu Wakabayashi ${ }^{2}$ \\ ${ }^{1}$ Laboratory of Aquatulture, Department of Aquatic Bioscience, Graduate School of Agicultural \\ and Life Sciences, The University of Tokyo, Maisaka, Hamana-gun, \\ Shizuoka 431-0211, Japan \\ ${ }^{2}$ Laboratory of Fish Diseases, Department of Aquatic Bioscience, Graduate School of \\ Agricultural and Life Sciences, The University of Tokyo, \\ Yayoi, Bunkyo, Tokyo 113-8657, Japan
}

(Received February 28, 2001)

\begin{abstract}
Seasonal occurrences of the abnormally enlarged ovary of Pacific oysters Crassostrea gigas caused by an unidentified intracellular protozoan parasite was investigated in Gokasho Bay, Mie Prefecture, Japan. Cultured and wild oysters were collected bimonthly for one year from July 1996, and seasonal fluctuations in the prevalence of infection, parasite development and histological changes of the infected tissue were examined. Parasites, very similar to Marteilioides chungmuensis infecting Pacific oysters in Korea, had 8 forms, 4 of which were frequently observed, while the other 4 forms, which were not described in $M$. chungmuensis, were rare. The total prevalence of infection (percentage of infected oysters positive for at least one of the two examinations: gross and smear inspections of the ovary) was usually higher than the gross prevalence of infection, indicating that infected oysters included ones without visible legions. In cultured oysters, the prevalence of infection increased in summer, suggesting that active multiplication of the parasite takes place in warm water months. From autumn through spring, no substantial change in the total prevalence of infection was observed in cultured oysters (18-20\%), while it continued to decline in wild oysters during that period. These differences between cultured and wild oysters could be attributed to the oyster size and environmental factors such as salinity. Histologically, the number of infected oocytes increased in summer, but decreased in winter. From the variations in the parasite morphology and maturation of oocytes, the life cycle of the parasite and the mechanism of the legion formation are postulated.
\end{abstract}

Key words: Pacific oyster, Paramyxea, parasite, oocyte, seasonality, Crassostrea gigas

Abnormally enlarged ovary of Pacific oysters Crassostrea gigas is a condition in which the ovary shows lumpy proliferation from autumn, when the reproductive season is over (Matsusato et al., 1977). This disease occurs in the western part of Japan. The pathogen is a protozoan parasite infecting the oocyte, but taxonomical studies on this parasite have not been made. The disease causes industrial problems because the gross sign of the lumpy ovary is responsible for a loss of commercial value of infected oysters.

\footnotetext{
* Corresponding author

E-mail: aogawak@mail.ecc.u-tokyo.ac.jp
}

Effective countermeasures have not been established.

Literature on this disease is quite limited, which prevents the development of countermeasures against the disease. Previously, Seki (1933), Ogasawara et al. (1962) and Matsusato et al. (1977) reported some basic aspects of the disease. However, their investigations were made in Hiroshima Prefecture, and little has been done on the disease in other localities. The kinetics of the disease may be different in different environmental conditions.

Comps et al. (1986) assigned Marteilioides chungmuensis infecting Pacific oysters in Korea, apparently 
very similar to the present parasite, to the phylum Ascetospora, which included mixed groups of mollucan parasites such as Haplosporidium, Minchinia and Marteilia. However, Anderson and Lester (1992) reasonably assigned their new species Marteilioides branchialis infecting Sydney rock oyster Saccostrea commercialis to the phylum Paramyxea, which is characterized by the formation of the typical cell-in-cell structure.

In Perkinsus marinus and Haplosporidium nelsoni, lethal protozoan parasites of Eastern oysters Crassostrea virginica, seasonal variations in the mortality and pathological conditions have been described (Crosby and Roberts, 1990; Haskin and Andrews, 1988), and the life cycle and infection routes have been inferred (Perkins, 1996; Volety and Chu, 1994). Particularly for $H$. costale, the pathogen of Sea Side Disease of Eastern oysters, it is possible to reduce mortality by adjusting the harvesting time, and thus the peak of mortality is avoided (Andrews et al., 1962; Elston, 1994).

Seasonal variations in this proliferative ovarian disease of oysters in Gokasho Bay are described in this paper to determine the seasonality in the parasite development, the disease progress, and to determine the invasion period of the parasite. The infection of cultured and wild oysters was examined once in every two months for one year from July 1996, and smears and tissues were examined for developmental stages of the parasite.

\section{Materials and Methods}

\section{Oyster examined}

Cultured and wild Pacific oysters, 100 each, from Gokasho Bay were examined for each sampling. Cultured oysters were purchased from a local fisherman; they consisted of a single stock of oysters, just 1-year old when we started the surveys. Wild oysters were collected in the intertidal zone in front of the National Research Institute of Aquaculture at Nansei, Mie Prefecture. Oysters were collected in July, October and December 1996 and March, May and July 1997. In July 1997, only cultured oysters were collected, because the number of wild oysters was severely reduced in summer.

After removing the right valve, oysters were grossly checked for the presence or absence of the abnormally enlarged ovary. Gonad smears were then prepared. Part of each gonad was placed on a glass slide, and thin smears were prepared with a cover glass and then airdried. The smears were stained with May-Grunwald and Giemsa or Diff-Quik stain, and mounted in Permount (Fisher Chemical Co., Ltd., USA).

For preparing tissue sections, oysters were fixed with $10 \%$ formalin or Davidson's solution (Shaw and Battle, 1957), and internal organs and gonads with gross abnormalities were cut about $3 \mathrm{~mm}$ thick. They were embedded in paraffin, and $5 \mu \mathrm{m}$-thick sections were prepared. Sections were stained with hematoxylin and eosin, and mounted in Permount. Tissue sections were not prepared in July 1996 because of mechanical failure. Hence, histological examinations on the infection of cultured oysters were made from October 1996 to July 1997. Data on wild oysters are not presented, because tissue sections were available only for 3 out of the 6 surveys.

\section{Gross and total prevalence of infection}

Infection was investigated both directly by the naked eye and in smears with a light microscope. The gross prevalence of infection was represented by the percentage of oysters with lumpy ovaries by the naked eye. The total prevalence of infection was defined as the percentage of oysters positive for at least one of the two examinations: confirmation of lumpy ovaries by the naked eye (visible disease signs) and detection of parasites in smears by light microscopy.

\section{Observations of the parasite and histopathology of the infected tissue}

The parasite and infected ovaries were observed in smears and tissue sections. Parasites were mainly investigated in smears. In tissue sections of cultured oysters, 100 oocytes were counted, of which the number of infected oocytes were counted, and parasites were categorized according to the developmental stages described in the Results. Oocytes were counted 3 times and the average for each month was tested with ANOVA (Statview ver. 3.0). Pathological changes were observed in tissue sections and the seasonal variations in the condition of the infected ovary were examined.

\section{Environmental conditions}

For environmental conditions, the data measured at National Research Institute of Aquaculture were used. Water temperature fluctuated between $13.2^{\circ} \mathrm{C}$ and $27.1^{\circ} \mathrm{C}$ and was highest in August and September. Salinity did not change markedly (32-33\%o).

\section{Results}

\section{Seasonal fluctuations in the infection}

The total prevalence of infection of Pacific oysters in Gokasho Bay is shown in Fig. 1. In both cultured and wild oysters, there was no case in which oysters had visible signs of disease, but was negative for parasites in smears. The total prevalence of infection was always slightly higher than the gross prevalence of infection, except for cultured oysters in March 1997, when no parasite was detected in smears from oysters negative for visual disease signs.

Cultured oysters were not infected in July 1996, but 

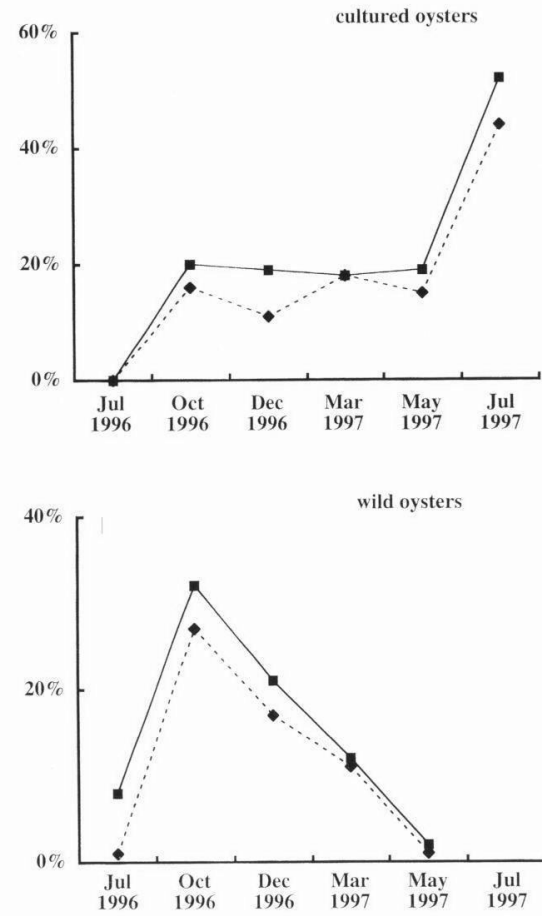

Fig. 1. The gross prevalence of abnormally enlarged ovary and the total prevalence of infection with the causative protozoan in Pacific oysters, Crassostrea gigas in Gokasho Bay. the total prevalence of infection reached $20 \%$ in October. Subsequently, there was no fluctuation in the total prevalence of infection up until May 1997, when it rose to $52 \%$ in July 1997 . In wild oysters, the total prevalence of infection was as high as $32 \%$ in October 1996 , but started to decline in December, and was only $2 \%$ in May 1997.

The sexes of oysters were examined, and all of the infected oysters were females. The sex ratio was about $1: 1$ during the reproductive season.

\section{Morphological changes of the parasite}

From observations of the smears, 8 forms of the ovarian parasite were recognized. The ratio of each form changed seasonally. These forms are designated as $\mathrm{A}$ to $\mathrm{H}$. They are illustrated in Fig. 2 and their photos are shown in Fig. 3. Their characteristics are tabulated in Table 1.

Among cultured oysters, the number of infected oocytes was reduced markedly from October to December $1996(P<0.05)$. The composition of the parasite forms also changed (Fig. 4). In October, type D parasites were most common, while in December, only types $A$ and $B$ were observed. In May 1997, the number of parasites increased $(P<0.05)$, and types $C$ and $D$ were
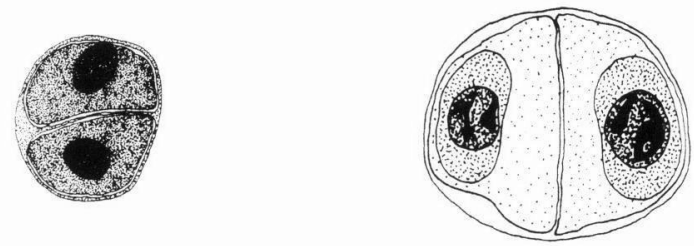

C

D
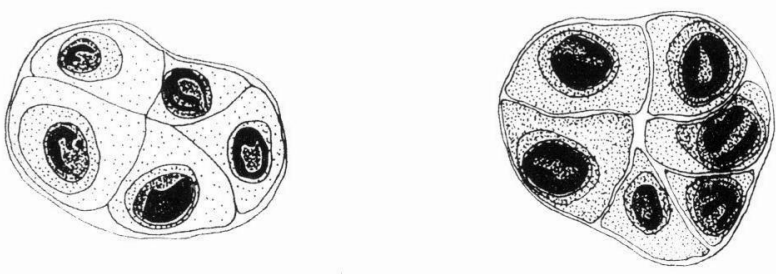

G

Fig. 2. Drawings of the parasites. See Table 1 for detailed explanation. 

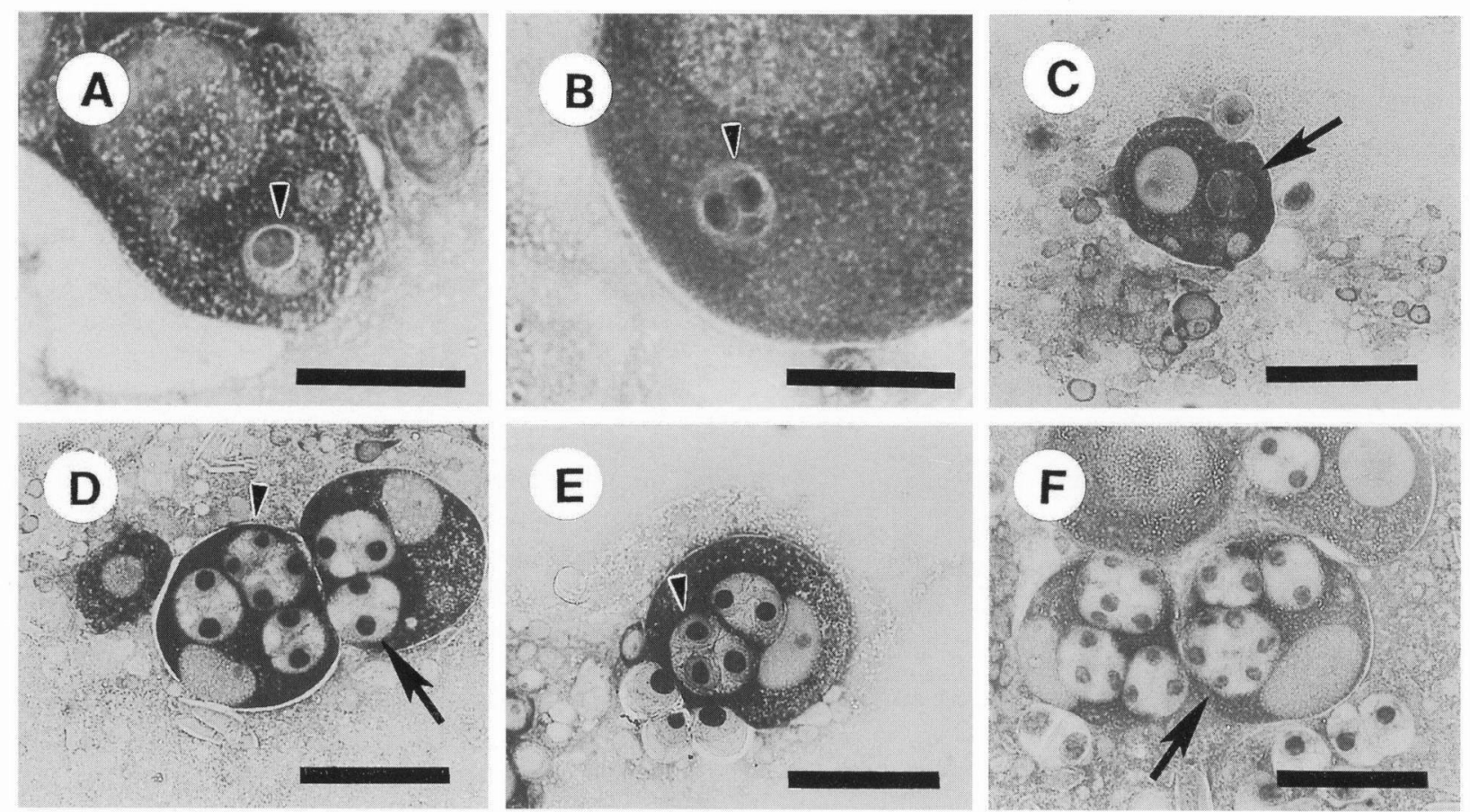

Fig. 3. Various forms of the parasite in the oocytes of cultured Pacific oyster, Crassostrea gigas. A, type A; B, type B (arrowhead); C, type C (arrow); D, type D (arrow), and type F (arrowhead); E, type E (arrowhead); F, type H (arrowhead). Scale bars: A, $\mathrm{B}=25 \mu \mathrm{m} ; \mathrm{C}$ to $\mathrm{F}=50 \mu \mathrm{m}$.

Table 1. Morphology of the causative parasite. The diameter, infected oocytes and characteristics of each type are shown

\begin{tabular}{|c|c|c|c|}
\hline Type & $\begin{array}{l}\text { Diameter } \\
(\mu \mathrm{m})\end{array}$ & Infected oocytes & Morphological characteristics \\
\hline A & $5-7.5$ & $\begin{array}{l}\text { mainly immature, } \\
\text { rarely matured } \\
\text { oocytes }\end{array}$ & $\begin{array}{l}\text { Include } 1 \text { nucleus and } 1 \\
\text { intracellular cell with } \\
\text { hematoxylin-positive inside } \\
\text { and eosin-positive outside }\end{array}$ \\
\hline $\mathrm{B}$ & $10-16$ & $\begin{array}{l}\text { mainly immature, } \\
\text { rarely matured } \\
\text { oocytes }\end{array}$ & $\begin{array}{l}\text { Included 2-7 intracellular cells, } \\
\text { similar to type A }\end{array}$ \\
\hline $\mathrm{C}$ & $17-20$ & $\begin{array}{l}\text { Immature to } \\
\text { mature oocytes }\end{array}$ & $\begin{array}{c}2 \text { intracellular cells with the } \\
\text { same staining as in types A \& B } \\
\text { occupying whole area of a } \\
\text { host cell }\end{array}$ \\
\hline D & $17-25$ & $\begin{array}{l}\text { mature oocytes } \\
\text { only }\end{array}$ & $\begin{array}{l}\text { Including } 2 \text { cell-in-cell } \\
\text { structures, with eosin-positive } \\
\text { outside and hematoxylin- } \\
\text { positive inside }\end{array}$ \\
\hline $\mathrm{E}$ & $17-25$ & $\begin{array}{l}\text { mature oocytes } \\
\text { only }\end{array}$ & $\begin{array}{l}\text { Including } 3 \text { cell-in-cell } \\
\text { structures like type D }\end{array}$ \\
\hline $\mathrm{F}$ & $17-25$ & $\begin{array}{l}\text { mature oocytes } \\
\text { only }\end{array}$ & $\begin{array}{l}\text { Including } 4 \text { cell-in-cell } \\
\text { structures like type D }\end{array}$ \\
\hline G & $17-25$ & $\begin{array}{l}\text { mature oocytes } \\
\text { only }\end{array}$ & $\begin{array}{l}\text { Including } 5 \text { cell-in-cell } \\
\text { structures like type D }\end{array}$ \\
\hline $\mathrm{H}$ & $17-25$ & $\begin{array}{l}\text { mature oocytes } \\
\text { only }\end{array}$ & $\begin{array}{l}\text { Including } 6 \text { cell-in-cell } \\
\text { structures like type D }\end{array}$ \\
\hline
\end{tabular}




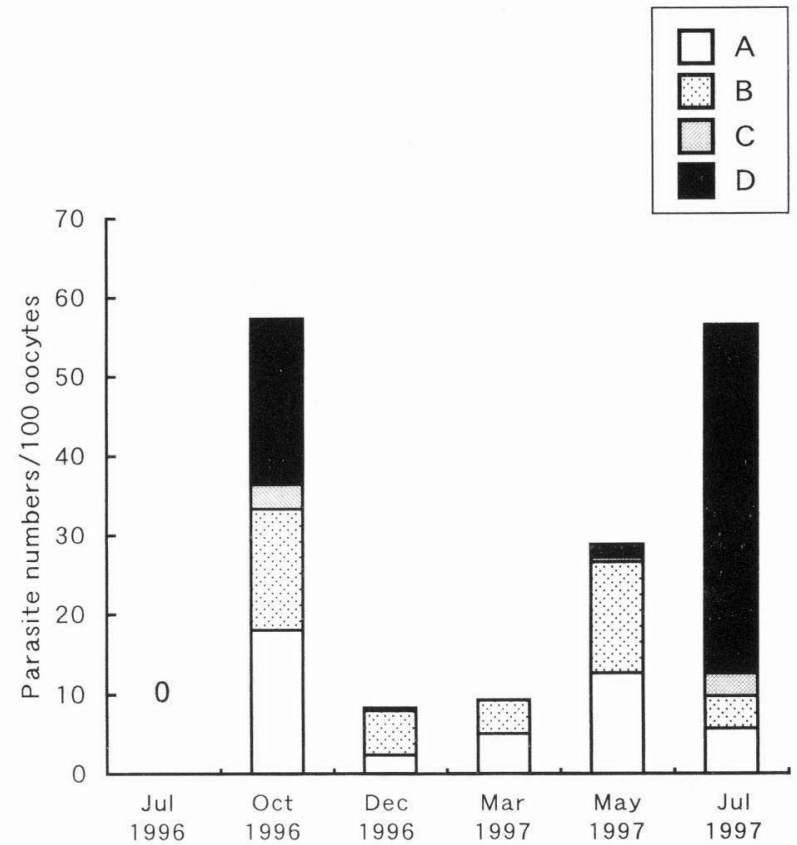

Fig. 4. Number of infected oocytes in 100 oocytes of Pacific oyster, Crassostrea gigas. Parasites were categorized as type $A, B, C$ or $D$.

observed. In July 1997, the number of parasites increased to as many as 54.5 in 100 oocytes examined $(P<0.05)$, and type D was dominant again.

\section{Histological examinations}

In cultured oysters, abnormally developed ovaries occurred only in some parts of the intergonadal connective tissue, forming infection foci. In tissue sections, seasonal changes in maturity of oocytes and the appearance of the parasite were observed as follows.

October 1996: Matured oocytes infected with type D parasites were observed in the lumen of the follicle, and immature oocytes infected with type A or B parasites attached to the follicle wall (Fig. 5A).

December 1996: Oocytes with type D parasites were rarely observed among mature oocytes in the lumen of the follicle. The number of immature oocytes on the follicle wall were considerably higher than that in October; some were infected with Type A and B parasites, but the ratio of infected oocytes to all immature ones was reduced (Fig. 5B). In some parts of the foci, hemocyte infiltration was observed. In extreme cases, hemocytes were observed to occupy the whole space of degenerative infection foci (Fig. 5C). In such cases, many type $D$ parasites were free from degenerative host cells. The cell-in-cell structures were stained bright red with eosin, which indicates the parasites were dead.

March 1997: Most oocytes were uninfected and became mature. Only type A or B parasites were observed in immature oocytes, with a very low rate of infection (Fig. 5D).
May 1997: Immature oocytes on the follicle wall grew to some extent, compared with those in March. Parasites, especially of type $B$, in immature oocytes increased. Mature oocytes infected with type C and D parasites were also observed in the lumen of the follicle. Hemocyte infiltration was seldom observed (Fig. 5E).

July 1997: The number of mature oocytes with type $D$ parasites increased. They were observed in almost all areas of the gonad. Few immature oocytes were observed. Most parasites were type D (Fig. 5F).

\section{Discussion}

The present parasite is morphologically very similar to Marteilioides chungmuensis, but identification was not given in this paper. The reasons are: 1) we have observed Types $\mathrm{E}-\mathrm{H}$, which were not described in the infected Pacific oysters in Korea (Park and Chun, 1989), and 2) no comparable electron microscopic studies have been conducted in the present species.

\section{Seasonal fluctuations in the infection}

Both in cultured and in wild oysters, the gross prevalence of the abnormally enlarged ovary increased from July to October 1996, which may reflect the seasonal infection cycle. In this period, oysters consume much glycogen for gametogenesis and spawning (Sugawara and Koganezawa, 1995) and many oysters appeared watery. After spawning, oysters are more likely to die because of high energy consumption (Harold et al., 1988), and it was in this period that the disease signs started to appear. Additionally, infected oysters could spawn in this season because oocytes infected with type $\mathrm{D}$ parasites were reduced. It may then be predicted that the pathogen was also present in sea water. In winter, hemocyte infiltration into the infection foci was observed in some infected oysters. Such infiltration occurred in uninfected oysters at the end of the spawning season in late summer to early autumn. Since no host response was observed against this intracellular parasite in other seasons, it was probably a normal host response associated with the degeneration of the remaining gonad, irrespective of infection. In contrast, the infection of an intracelluar microsporean parasite in the ovocytes of Sydney rock oysters Saccostrea commercialis was accompanied by an intense hemocyte infiltration throughout the entire gonad (Anderson et al., 1995). Both the present parasite and the microsporean infect the ovocyte of oysters, but host response and their pathological effects may be quite different between the two parasites.

There are two possible reasons for the gross prevalence declined from October 1996 onwards in wild oysters: oysters either recovered or were dead. Recovery is possible if infections are lost via spawning. Besides, 

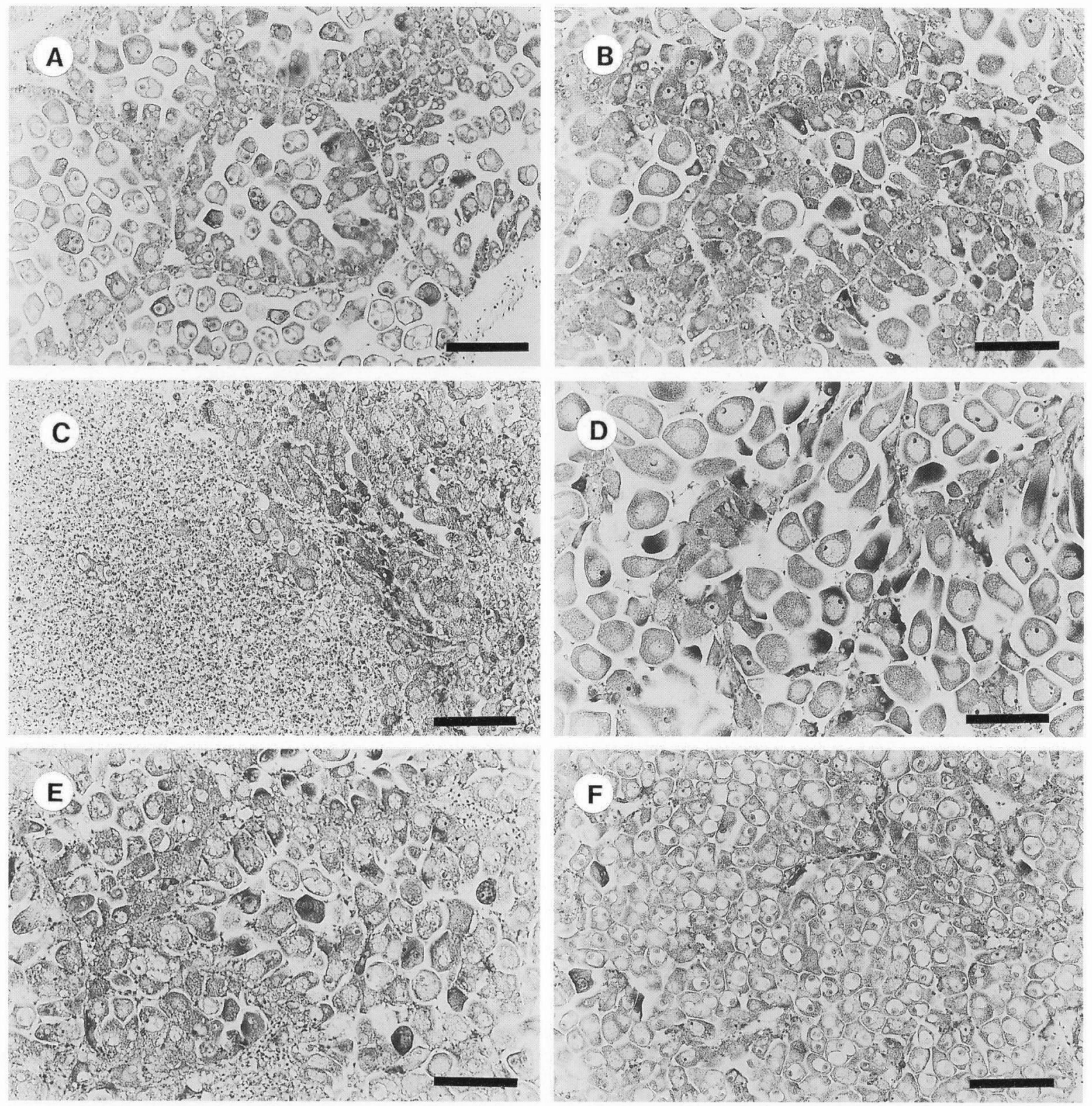

Fig. 5. Seasonal variations in the structure of infected ovary. A, October 1996. Matured oocytes infected with type D parasites were observed free in the center of follicles. Scale bar: $200 \mu \mathrm{m}$. B, December 1996. Parasites were rarely observed in matured oocytes. Scale bar: $200 \mu \mathrm{m}$. C, December 1996. Hemocytes were infiltrated in the infection foci. Scale bar: $200 \mu \mathrm{m}$. D, March 1997. The number of parasites was markedly reduced, and many uninfected mature oocytes were observed. Scale bar: $100 \mu \mathrm{m}$. E, May 1997. The number of parasites increased, and type C and D were observed again. Scale bar: $100 \mu \mathrm{m}$. F, July 1997. Most oocytes became matured and infected with type D parasites. Scale bar: $200 \mu \mathrm{m}$.

the hemocyte infiltration in the infected tissue in winter was similar to that in normal gonads after spawning (Sugawara, 1981). The infection foci may return to a normal tissue after the hemocyte infiltration. However, the phagocytosis by oyster hemocytes is not effective for protozoan parasites such as Perkinsus marinus (see Mori, 1995). Additionally, infected oysters were watery. Hence, in wild oysters, infected individuals are more likely to be killed by the disease.

On the other hand, the gross prevalence in cultured oysters did not change in winter, implying that infected oysters were not killed. Cultured oysters had shells about $10 \mathrm{~cm}$ high, whereas those of wild oysters were about $5 \mathrm{~cm}$. In bivalves, the bigger the body size becomes, the more the food is filtered (Navarro and Winter, 1982), and the excess energy consumption due to the disease may be supplemented. The time of feeding for wild oysters is limited by the period when they emerge from the water at low tide. Cultured oysters are grown offshore where salinity is higher than in the inter- 


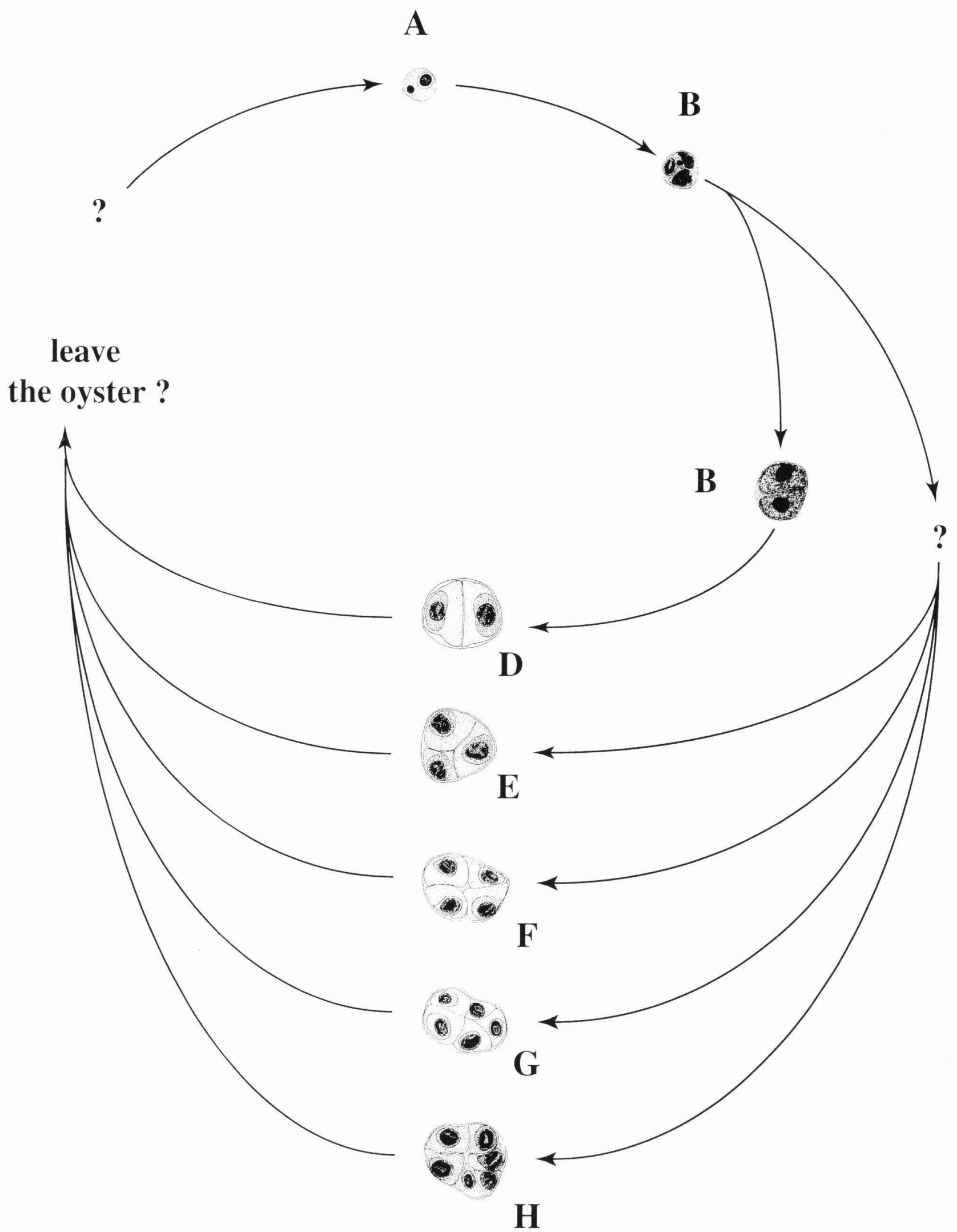

Fig. 6. Postulated life cycle of the parasite. 
tidal areas that wild oysters inhabit (Abo et al., 1997). High salinity is suitable for the growth of Pacific oysters. From these conditions, cultured oysters would be more resistant to mortality than wild oysters. However, infected oysters were watery as in wild oysters, hence they may also be killed later.

With these factors, the increased gross prevalence of infection in cultured oysters in July 1997 could be due to the low or negligible rate of mortality of infected oysters and a new appearance of the disease. In tissue sections, infected oocytes and the ratio of large parasites (mostly type D) increased. This could be due to the active multiplication of the parasite, and this may support the assumption that newly infected oysters appeared in summer. In wild oysters, because of the severe decrease in glycogen caused by the disease, hosts died before the parasite increased, and multiplication of the parasite was disturbed.

Seki (1933) reported that the gross prevalence of infection decreased in winter and increased from summer to autumn in Hiroshima Bay. In Gokasho Bay, however, no such seasonal fluctuations in the gross prevalence were recognized in cultured oysters. To determine the seasonality of the infection and the timing of the earliest appearance of noticeable disease signs, as predicted from the data on the gross prevalence, further examination with shorter sampling intervals will be required.

\section{Life cycle of the parasite}

Seasonal variations in the morphology of the parasite may be due to the progress of the parasite's life cycle. We assume the life cycle as in Fig. 6, from comparison with Marteilia refringens (see Figueras, 1988) and Marteilioides chungmuensis (see Park and Chun, 1989), the latter parasite causing similar ovarian disease in Korea and belonging to the same phylum, Paramyxea. Type A and B should be early stages and change to type $C$ and $D$ from spring to summer. Types $E$ to $H$ may be divided forms of type $D$, because type $F$ parasites appeared to be type $D$ parasites that had divided again. They may divide in summer because type D parasites increased in July 1997 . Types $E$ to $H$ were rarely observed. This may be because type $D$ rarely divides, or these stages may not be stable. However, as in $M$. chungmuensis, it is not known how the parasite leaves the host. Type $D$ is assumed to be the spore stage here, but the spore of $M$. refringens was markedly different from type $D$. Additionally, presence or absence of other hosts except oysters involved in the life cycle is not known.

The parasite was observed even in small immature oocytes. This indicates that oocytes became infected while they were in very early developmental stages. In M. chungmuensis, a morphologically similar species to the present parasite, an earlier developmental stage than type A in this study, designated as the 'root cell', was detected in the oocytes (Park and Chun, 1989). The parasite in this study could have such forms, which remain in the body of oysters and start to develop when the host condition is favorable to the parasite.

For the elucidation of the life cycle of this parasite, information on the route of infection is required. With the reduction in the number of infected oocytes in autumn, infected oocytes could be spawned and ingested by other oysters through the feeding current. On the other hand, infected oysters could be killed, because their soft tissues were shown to be watery. Hence, like Perkinsus parasites, the parasite might be washed away in the sea water and change their forms after the hosts were killed (Goggin and Lester, 1995).

The progress of the disease appears to be related to the glycogen content of the host, because infected oysters were shown to be watery, indicative of a much reduced glycogen level. Additionally, the appearance of this disease could be related to gametogenesis in the ovary, where the infection is restricted. To determine the timing of infection and first appearance of noticeable disease signs, the relationship between the physiological condition of oysters and the infection cycle should be elucidated.

\section{Acknowledgments}

We thank Drs. Y. Inui and K. Ashida, both then National Research Institute of Aquaculture (NRIA), now South East Asian Fisheries Development Center, lloilo, the Philippines and National Research Institute of Fisheries and Environment of Inland Sea, Hiroshima Prefecture, respectively, who gave us information about the disease in Gokasho Bay and the opportunity to undertake research there. We sincerely thank Mr. Y. Maeno and Dr. T. Kamaishi, NRIA, for their help with sampling oysters. We are also grateful for Dr. Craig. J. Hayward for his advice on the English usage.

\section{References}

Abo, K., S. Toda, T. Sakami and S. Yamamoto (1997): Effects of wind on oceanographic conditions of Gokasho Bay. Bull. Natl. Res. Inst. Aquacult. 26, 27-34. (In Japanese)

Anderson, T. J. and R. J. G. Lester (1992): Sporulation of Marteilioides branchialis n. sp. (Paramyxea) in the Sydney rock oyster, Saccostrea commercialis: an electron microscope study. J. Protozool., 39, 502-508.

Anderson, T. J., P. M. Hine and R. J. G. Lester (1995): A Steinhausia-like infeciton of the ovocytes of Sydney rock oysters Saccostrea commercialis. Dis. Aquat. Org., 22, 143-146.

Andrews, J. D., J. L. Wood and H. D. Hoese (1962): Oyster mortality studies in Virginia: III. Epizootiology of a disease caused by Haplosporidium costale Wood and Andrews. J. Insect Pathol., 4, 327-343.

Comps, M., M. S. Park and I. Desportes (1986): Etude ultrastructurale de Marteilioides chungmuensis n.g., n.sp. 
parasite des ovocytes de l'huitre Crassostrea gigas Th. Protistologica, 22, 279-285.

Crosby, M. P. and C. F. Roberts (1990): Seasonal infection and intensity cycle of the parasite Perkinsus marinus (and an absence of Haplosporidium spp.) in oysters from a South Carolina salt marsh. Dis. Aquat. Org., 9, 145-155.

Elston, R. A. (1994): Diseases of shellfish, Haplosporidiosis of American oysters. In "Blue book, suggested procedures for the detection and identification of certain finfish and shellfish pathogens, Version 1" (ed. by J. C. Thoesen). Am. Fish. Soc., Bethesda, $3 \mathrm{p}$.

Figueras, A. J. (1988): Aber disease of edible oysters caused by Marteilia refringens. Amer. Fish. Soc. Spec. Pub., 18, $38-46$.

Goggin, C.L. and R. J. G. Lester (1995): Perkinsus, a protistan parasite of abalone in Australia: A review. Mar. Freshw. Res., 46, 639-646.

Harold, J. B., J. P. Davis, S. L. Downing and K. K. Chew (1988): Summer mortality of Pacific oysters. Am. Fish. Soc. Spec. Publ., 18, 265-268.

Haskin, H. H. and J. D. Andrews (1988): Uncertainties and speculations about the life cycle of the Eastern oyster pathogen H. nelsoni (MSX). Am. Fish. Soc. Spec. Publ., $18,5-22$.

Matsusato, T., T. Hoshina, Y. Arakawa and K. Matsumura (1977): Study of the 'abnormal egg mass' of the Pacific oyster, Crassostrea gigas (Thunberg)-I. Bull. Natl. Res. Hiroshima, 8, 9-25. (In Japanese)

Mori, K. (1995): The immunoresponce system of shellfish. In "Oysters, scallops, and abalones" (ed. by Y. Sugawara). Koseisha Koseikaku, pp. 181-194. (In Japanese)

Navarro, J. M. and J. E. Winter (1982): Ingestion rate, assimila- tion efficiency and energy balance in Mytilus chilensis in relation to body size and different algal concentrations. Mar. Biol., 67, 255-266.

Ogasawara, Y., U. Kobayashi, R. Okamoto, A. Furukawa, M. Hisaoka and K. Nogami (1962): The use and productional meaning of the restriction in the oyster culture. Bull. Natl. Res. Inst. Inland. Fish., 19, 1-152.

Park, M. and S. Chun (1989): Study on Marteilioides chungmuensis Comps et al., 1986 parasite of the Pacific oyster, Crassostrea gigas Thunberg. J. Fish Pathol., 2, 53-70.

Perkins, F. O. (1996): The structure of Perkinsus marinus (Mackin, Owen, and Collier, 1950) Levine, 1978 with comments on taxonomy and phylogeny of Perkinsus spp. J. Shell. Res., 15, 67-87.

Seki, H. (1933): The abnormal development of the oyster gonads in Hiroshima Bay. Bull. Japan. Sci. Soc., 9, 9399. (In Japanese)

Shaw, B. L. and H. I. Battle (1957): The gross and microscopic anatomy of the digestive tract of the oyster, Crassostrea virginica (Gmelin). Can. J. Zool., 35, 325-347.

Sugawara, Y. (1981): Gametogenesis of the bivalve. Sci. Biol., 19, 629-639. (In Japanese)

Sugawara, Y. and A. Koganezawa (1995): The development of culture technology: Oysters. In "Oysters, scallops, and abalones" (ed. by Y. Sugawara). Koseisha Koseikaku, Tokyo. pp. 1-17. (In Japanese)

Volety, A. K. and F.-L. E. Chu (1994): Comparison of infectivity and pathogencity of meront (trophozoite) and prezoosporangiae stages of the oyster pathogen Perkinsus marinus in Eastern oysters, Crassostrea virginica (Gmelin, 1791). J. Shellfish Res., 13, 531-537. 